\title{
Formulation and Evaluation of the Antidiabetic, Hypolipidemic and Antioxidant Potential of the Tablets of Arbortristoside-A from the Seeds of Nyctanthes arbortristis Linn.
}

\author{
Sanjita Das*, Irfan Khan, Shruti Dhasmana, Shivani Shrivastava, KM Renu Singh \\ Noida Institute of Engineering and Technology (Pharmacy Institute), Plot No-19, Knowledge Park-II, Greater Noida, \\ Uttar Pradesh, INDIA.
}

\begin{abstract}
Aim: Literature shows the traditional as well as scientific proven medicinal importance of Nyctanthes arbortristis Linn. In the it was aimed at to formulate and screen the antidiabetic, hypolipidemic and antioxidant properties of the tablets of arbortristoside-A obtained from N. arbortristis seeds. Materials and Methods: Arbortristoside-A was chemically isolated from the seeds' ethanolic extract of $N$. arbortristis. The antioxidant property of arbortristoside-A was screened in-vitro by the help of DPPH (2,2-diphenyl-1picrylhydrazyl) methodology. The granules of arbortristocide-A with suitable excipients were prepared by wet granulation method. The tablets were prepared by the help of rotating punch tablet machine and subjected to standard evaluation process. Its antidiabetic property was evaluated by using streptozotocin-induced diabetic wistar rats of either sex. This study also included a serum biochemical assays and pancreatic and hepatic histopathological modification. Results: Daily oral treatment with tablets of arbortristoside-A and glibenclamide $(10 \mathrm{mg} / \mathrm{kg})$ for three weeks reduced the plasma glucose, cholesterol, triglycerides, AST and ALT levels significantly whereas improvement in HDL-cholesterol level was observed $(p<0.01)$ as that of the diabetic control animals. Significant recovery of the pancreas and liver was observed with the tablets administration which was supported by its significant antioxidant activity. Conclusion: Present results indicated that the tablets of arbortristoside-A have prominent effect in the overall management of diabetes mainly at its higher dose $(75 \mathrm{mg} / \mathrm{kg})$ in the diabetic due to its antilipidemic and antioxidant properties.
\end{abstract}

Key words: Antioxidant, antidiabetic, tablet, arbostristoside-A, DPPH, streptozotocin, histopathology.

\section{INTRODUCTION}

The increased occurrence of diabetes and the consequences of its complications such as hyperlipidemia due to decrease in High Density Lipoprotein (HDL), high triglycerides and Low Density Lipoprotein (LDL) levels represents the greatest health care challenge. Exploration of plants for the treatment of diabetes has been carried out since centuries. The earlier medicines for diabetes were obtained from herbs and principal medicinal plants. Due to the toxic effect of various synthetic drugs, most efforts would be done to substitute them with relatively harmless, cheaper and effective herbal drugs for the treatment of diabetes. Nyctanthes arbortristis Linn (Family. Oleaceae) is having wide distribution in India, specifically in the sub-Himalayan regions and southwards to Godavari along with its ornamental plantation. ${ }^{1}$ In Odisha, India use $N$. arbortristis is used by folk people to cure different disorders along with its use in traditional systems of medicines. These therapeutic uses have also
Submission Date: 18-04-2021; Revision Date: 02-08-2021; Accepted Date: 10-09-2021

DOI: 10.5530/ijper.55.4.208 Correspondence: Dr. Sanjita Das, Noida Institute of Engineering and Technology (Pharmacy Institute), Plot No-19, Knowledge Park-II, Greater Noida, Uttar Pradesh, INDIA. Phone: +919818223359 ,

Email - sanjita8@yahoo. co.in

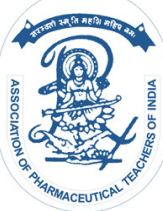

www.ijper.org 
been scientifically proven. ${ }^{1-13}$ Literature shows the scientific work on its chemical componenents like beta-sitosterol, polysaccharides, nyctanthoside, arbortristoside-A, B and C. ${ }^{4-6}$ Arbortristocide-A is an established compound, which has been found to be present in different parts of $N$. arbortristis. The antiplasmodial, ${ }^{6}$ leishmanicidal, ${ }^{7}$ antiallergic activities ${ }^{8}$ and antispermatogenic, ${ }^{9}$ anti-arthritic ${ }^{10}$ and anti-proliferative effect on acute and chronic primary human leukemia cells ${ }^{11}$ have been reported for arbortristoside-A and B. It has already been established that ethanolic extracts of different parts and arbortristoside-A are hematologically nontoxic and arbortristoside-A is responsible for their anti-inflammatory activity. ${ }^{12,13}$ Suresh et al. (2010) and Suresh and Senthilkumar (2018) had evaluated the antidiabetic activity of the stem bark of $N$. arbortristis, whereas Vajravijayan et al. (2020) evaluated that of arbortristoside-C from $N$. arbortristis and observed significant antidiabetic activity similar to the standard drug. ${ }^{14,15}$

Keeping in view of growing concern for the management of diabetes and the past scientific evidence for hypoglycaemic potentiality of this selected plant, the present study aimed to scientifically establish the tablet formulation of arbortristoside-A isolating from the ethanolic extract of the seeds of $N$. arbortristis for the overall management of diabetes in any group of diabetic patients for the socio-economic benefit. As oxidative stress causes health hazards in diabetic patients, the antioxidant property of arbortristoside-A was conducted to support the present research target. As the diabetes leads to hyperlipidaemia, it has been planned to screen the effect of arbortristoside-A against the diabetis induced hyperlipidaemia.

\section{MATERIALS AND METHODS}

\section{Preparation of the plant extract}

The collection of $\mathrm{N}$. arbortristis was done from the gardens of Odisha during the December to February. Afterwards the plant (CNH/I-I (20)/2005-Tech-II/254) authentication was carried out as N. arbortrisis (Fam. Oleaceae) from Botanical Surbey of India, Kolkata. The properly dried seeds ere coarsly powedered and then subjected to extraction gradually with petroleum ether, chloroform and ethanol $(90 \%)^{7,12}$ and finally the ethanolic extract was concentrated for further processing.

Isolation of arbortristoside-A: After dissolving the concentrated ethanolic extract was fractionated with diethylether, ethyl acetate and n-butanol, out of which the $\mathrm{n}$-butanol fraction $(50.32 \% \mathrm{w} / \mathrm{w})$ was subjected to drying and then triturated with aceton. A solid mass was separated out which was further washed with $2 \mathrm{~N}$ hydrochloric acid and then with hot distilled water and further crystallization was conducted with chloroform:methanol (1:1). ${ }^{5,13}$ It provided a light yellow coloured crystalline powder with yield value 5.25\% w/w. It was further subjected to phytochemical and spectral analysis to identify the type of compound..$^{13-19}$

\section{Preparation of the tablet formulation of arbortristoside-A}

The tablets of $50 \mathrm{mg}$ and $75 \mathrm{mg}$ of arbortristoside-A were prepared by wet granulation method using rotating punch tablet machine. The prepared tablets were subjected to standard evaluation process as performed in previous investigation on the bioavailability study of its prepared formulation. ${ }^{20}$ Tablets from different formulations were evaluated for various parameters such as diameter (dial caliper), thickness (dial caliper), weight variation test and friability (Roche friabilator), hardness (Pfizer hardness tester). Disintegration time (Veego disintegration apparatus) was determined using distilled water as disintegration media.

\section{In-vitro and In-vivo evaluation of the tablet formulation}

The in-vitro release of extracts and arbortristoside- $A$ from the tablet was determined using the USP II rotating basket dissolution apparatus, where phosphate buffer of $\mathrm{pH} 7.2$ was used as the dissolution medium. The stirring rate was $100 \mathrm{rpm}$ and the temperature was maintained at $37^{\circ} \mathrm{C}$. Aliquots were withdrawn at an interval of $5 \mathrm{~min}$ and were analyzed by injecting onto HPLC method and analyzed at $235 \mathrm{~nm}$. The amount of drug dissolved was plotted versus time to represent the rate of dissolution.

All the pharmacokinetic parameters of the tablets of arbortristoside-A were calculated with the help of in-vivo data, where six wistar albino rats were used. The dosage forms were administered orally with the help of a gastric gavage tube after crushing to a fine powder by mortar and pestle and mixing homogeneously prior to oral using $0.1 \%$ DMSO solution as the solvent. The blood sample were collected at $0 \mathrm{hr}, 30 \mathrm{~min}, 1 \mathrm{hr}, 2 \mathrm{hr}$, $3 \mathrm{hr}, 4 \mathrm{hr}$ and $5 \mathrm{hr}$ in heparinized tubes. Immediately plasma was centifused at $1500 \mathrm{rpm}$ for $15 \mathrm{~min}$ and the supernatant was collected and subjected to HPLC for analysis at $235 \mathrm{~nm}$. The AUC 0-5 (Area under the curve from $0 \mathrm{hr}-5 \mathrm{hr}$ ) was plotted as plasma concentrationtime curve following trapezoital rule, from which the $\mathrm{C}_{\max }$ (Maximum Plasma Concentration) and $\mathrm{T}_{\max }$ (Time 
required to reach the maximum concentration) were calculated using software Kinetica. ${ }^{20-22}$

\section{Antioxidant activity of arbortristoside-A by DPPH method}

The in-vitro antioxidant activity of arbortristoside-A was evaluated using DPPH radical scavenging test as previously detailed. ${ }^{23}$ In this study ascorbic acid was taken as standard antioxidant agent. By the help of UV-Visible spectrophotometer the aborbaance was measured at $525 \mathrm{~nm}$. The free radical scavenging activity of arbortristoside-A was estimated by the following formula.

DPPH radical scavenging activity $(\%)=\frac{1-\left(\mathrm{Abs}_{\text {sample }}-\mathrm{Abs}_{\text {blank }}\right)}{A b s_{\text {control }}} \times 100$

Where $\mathrm{Abs}_{\text {sample, }} \mathrm{Abs}_{\text {blank }}$ and $\mathrm{Abs} \mathrm{s}_{\text {control }}$ represent the aborbance due to sample, blank and control respectively and each of the absorbance is recorded thrice.

\section{Animals}

For the present research wistar albino rats (150-250 g) of either sex were utilized for exploring the overall treatment diabetes. Standard environment condition, standard pellet food and water Animals were maintained under standard environmental condition along with standard pellet food and water ad libitum. They were also facilitated with $12 \mathrm{hr}$ each of dark and light cycle. The research portion with the experimental animals was conducted with ethical principles and guidelines provided by Committee for the Purpose of Control and Supervision on Experiments on Animals (CPCSEA) and Organization for Economic Co-operation and Development (OECD). With due regards to the guidelines the experimental protocol was approved by Institutional Animals Ethics Committee of Noida Institute of Engineering and Technology (Pharmacy Instittttute), Greater Noida (Regn No. 1845/PO/Re/S/16/CPCSEA).

\section{Antidiabetic activity of arbortristoside-A}

The animals $(n=30)$ were randomly distributed between 5 groups with 6 animals in each group.

Group-I: Normal control group which was treated with $0.1 \%$ DMSO solution (solvent).

Group-II: Positive diabetic control group; treated with streptozotocin. Streptozotocin (STZ, Sigma, USA) was dissolved in $0.1 \mathrm{M}$ cold citrate buffer $(\mathrm{pH} 4.5)$ was administered intraperitoneally at a dose of $35 \mathrm{mg} / \mathrm{kg}$ body weight. By oberving the blood glucose above $250 \mathrm{mg} / \mathrm{dl}$ at $96 \mathrm{hr}$ of STZ administration, the animals were considered to be diabetic and were used in the investigation. ${ }^{21,22}$
Group-III: Standard group where diabetic animals were treated with glibenclamide $(10 \mathrm{mg} / \mathrm{kg}$ b.w.) orally daily for three weeks.

Group-IV and group-V: The test groups where the dibetic rats were orally administered with the tablet formulation of arbortristoside-A (50 and $75 \mathrm{mg} / \mathrm{kg}$ body weight respectively as decided from the toxicity studies performed under previous investigations) $)^{24-26}$ by a gastric gavage after crushing and mixing homogenously the tablet formulation in $0.1 \%$ DMSO solution for 3 weeks.

The blood glucose level was estimated by getting the blood sample from the tail vein of the experimental animals on $0,7^{\text {th }}, 14^{\text {th }}$ and $21^{\text {st }}$ day of treatment using Easy GlucoTM Blood Glucose Meter (ISENS Biosensors India Pvt. Ltd., Guragon, India). At the end of the 21 days, after collecting the blood sample by cardiac puncture for biochemical analysis, the overnight fasted animals were euthanized using high dose of isofurane and their internal organs like the pancreas and liver were immediately removed for their histopathological study. ${ }^{24-26}$

\section{Biochemical parameters}

Blood from the treated and untreated animals was collected in a tube without anticoagulant to separate the serum. The serum was separated by centrifusing the blood sample at $2,500 \mathrm{rpm}$ for $15 \mathrm{~min}$ and was utilized for biochemical assays. Serum triglycerides, cholesterol and High-Density Lipoprotein (HDL) levels were evaluated by the help of kits (Roche Diagnostics $\mathrm{GmbH}$, Mannheim, Germany). Serum levels of Alanine Transferase (ALT) and Aspartate Transaminase (AST) were calculated by an auto analyzer (Erba Chem 7, Mannheim, Germany). ${ }^{2425}$

\section{Histopathology of liver and pancreas}

Tissues were preserved in 10\% formalin for $24 \mathrm{hr}$ to rectify the shrinkage. The tissues were dehydrated by immersing the tissues in isopropanol (80\%) overnight and then $100 \%$ isopropyl alcohol for $1 \mathrm{hr}$. The tissues were emerged in wax and mounted in paraffin blocks. A rotary microtome was used to cut the paraffin blocks with at 3-micron thickness and then were melted in an incubator and cooled. Afterwrds the obtained sections were deparaffinized by immersing in xylene and further were stained in hematoxylin and counter stained with $1 \%(\mathrm{w} / \mathrm{v})$ aqueous eosin for $1 \mathrm{~min}$. The dehydration of the stained sections was carried out in the incubator at $60^{\circ} \mathrm{C}$ for $5 \mathrm{~min}$. After proper cooling of the sections, the sections were stained with xylene and were staged in diphenyl xylene (DPX) mount. The histology was evalu- 
ated under low power objective lens and the cell injury was observed under high power objective lens and over aspects were observed..$^{24,25}$

\section{Statistical analysis}

The observed values in the present research were represented as mean \pm SEM. The data interpretation was carried out using analysis of variance (ANOVA) and different group mean were compared by using Dunnett's test by the help of GraphPad Instat. The observed results were considered to be significant with $p<0.01$.

\section{RESULTS AND DISCUSSION}

\section{Isolation of arbortristoside-A}

It has been observed from the preliminary phytochemical tests that the isolated compound was iridoid glucoside with mp $225-228^{\circ} \mathrm{C}$, [ $\left.\alpha\right] \mathrm{D} 25-92^{\circ}(\mathrm{MeOH})$ was observed as an iridoid glucoside. The isolated compound showed UV (MeOH): 206, 227, 300 and 308nm; IR bands (KBr, $\mathrm{MeOH}): 3424,2950,1719,1662,1633,1514,1450,1377$, 1216, 1177, 1050, 877, 835, 750, $591 \mathrm{~cm}^{-1}$; 1H-NMR and ${ }_{13}$ C-NMR (400MHz, DMSO-d6) data; Ms (m/z): 371, 226, 200, 178, 161, 139. The UV spectral data suggested the presence of esters, $-\mathrm{O}-\mathrm{C}=\mathrm{C}-\mathrm{CO}_{2} \mathrm{CH}_{3}$, phenyl groups and $p$-substituted benzene ring. The UV spectral data also suggested the presence of esters, $-\mathrm{O}-\mathrm{C}=\mathrm{C}-\mathrm{CO}_{2} \mathrm{CH}_{3}$, phenyl groups and $p$-substituted benzene ring. The IR spectral data of the isolated compound showed the presence of monosubstituted aromatic system $\left(750 \mathrm{~cm}^{-1}\right)$, esters (1177, $\left.1216 \mathrm{~cm}^{-1}\right),-\mathrm{CH}_{3}\left(1377 \mathrm{~cm}^{-1}\right),-\mathrm{C}=\mathrm{C}$ $\left(1662 \mathrm{~cm}^{-1}\right)$ and $-\mathrm{OH}\left(3424 \mathrm{~cm}^{-1}\right)$ groups. The NMR spectral data revealed that the isolated component may have trans-olefinic protons $(\delta$ 6.95), $-\mathrm{C}=\mathrm{C}-\mathrm{H}$ group $(\delta 4.7)$, esters ( $\delta 4.1$ and $\delta 3.7),-\mathrm{OH}(\delta 2.7)$ and $-\mathrm{CH}_{3}$ $(\delta$ 1.03) groups (Table 1$)$. The mass spectral analysis represented the major fragments like $[\mathrm{c}]^{+}(371),[\mathrm{a}]^{+}$ (226), $\left[\mathrm{a}-\mathrm{H}_{2} \mathrm{O}\right]^{+}(200)$, -methoxy cnnamic acid (178), p-methoxy cinnamoyl moiety (161), [b] $]^{+}$(139) (Table 2). The molecular weight was calcilated as 548.0 and corroborated the structure of the isolated compound. Finally the isolated compound was confirmed to be arbortristoside- $\mathrm{A}, \mathrm{C}_{27} \mathrm{H}_{34} \mathrm{O}_{13}$ (Figure 1) as reported earlier. ${ }^{13,17-19}$ The further pharmacological activities of the bioactive compound were conducted by using DMSO (1\%) as the solvent for arbortristoside-A.

\section{In-vitro and in-vivo evaluation of the tablet formulation of arbortristoside-A}

From the in-vitro study, the release rate of arbortristoside-A was observed to be $70 \%$. In the in-vivo bioavailability study of the tablets of arbortristoside-A, the blood plasma values at different time intervals showed equivalent comparative results to that of its in-vitro study results so as to reveal a bioanalogus in-vitro performance of its tablet formulation in a systematic manner. The pharmacokinetic data were analyzed from the obtained plasma concentrations of arbortristosideA. The $\mathrm{C}_{\text {max }}$ was measured as $52.8 \mu \mathrm{g} / \mathrm{ml}$ and $\mathrm{t}_{\max }$ was found to be at $2 \mathrm{hr}$ for arbortristoside-A for its tablet formulation. It was also observed that after $4 \mathrm{hr}$ its plasma concentration was going towards low level showing its effectiveness to be within this period. It was also considered during its pgharmacological evaluations.

\section{Antioxidant activity of arbortristoside -A}

Strong antioxidant activity was observed by arbortristoside -A following DPPH radical scavenging experiment. Ascorbic acid showed DPPH radical scavenging activity (22.68 \pm 1.78$)$ and scavenging activity of arbortristosideA showed $20.67 \pm 1.57$ at $6.25 \mu \mathrm{g} / \mathrm{ml}$ concentrations. At $12.5 \mu \mathrm{g} / \mathrm{ml}$ concentration scavenging activity of ascorbic acid was $60.37 \pm 2.34$ while arbortristoside -A showed $58.38 \pm 1.96$. DPPH radical scavenging activity increased to $84.21 \pm 3.21$ of ascorbic acid and $80.67 \pm 2.81$ of arbortristoside -A at $25 \mu \mathrm{g} / \mathrm{ml}$. At $50 \mu \mathrm{g} / \mathrm{ml}$ concentration ascorbic acid showed $91.56 \pm 2.67$ and arbortristoside $-\mathrm{A}$ showed $85.71 \pm 2.15$ scavenging activity. At $100 \mu \mathrm{g} / \mathrm{ml}$ concentration scavenging activity of ascorbic acid was $95.76 \pm 2.57$ while arbortristoside $-A$ showed $93.43 \pm 2.45$ (Table 3). Compared to ascorbic acid displaying $50 \%$ scavenging activity (RS50) at $10.4 \mu \mathrm{g} / \mathrm{mL}$, the arbortristoside-A exhibited RS50 at $18.0 \mu \mathrm{g} / \mathrm{mL}$ on this test. The antioxidant effects of arbortristoside $-\mathrm{A}$ on DPPH may be due to their ability of hydrogen donation. ${ }^{27}$ Though the DPPH radical scavenging abilities of arbortristoside -A were less than those of ascorbic acid, our study showed that arbortristoside -A could serve as free radical scavengers and possess antioxidant property. Literature shows that diabetic complications are developed by the improved generation of oxygen free radicals which has been connected with glucose oxidation and nonenzymatic glycation of proteins. Administration of antioxidants have scientifically proven to be protective against the free radicals in diabetes. For the development of diabetes increased oxidative stress is one of the major factors. ${ }^{28}$ Antioxidants are also proved to protect from the active oxygen species and increase the ability of some enzymes action. ${ }^{29}$

\section{Antidiabetic activity}

The present screening showed a significant $(p<0.01)$ increase in the blood glucose level from $247.8 \pm 8.42$ 


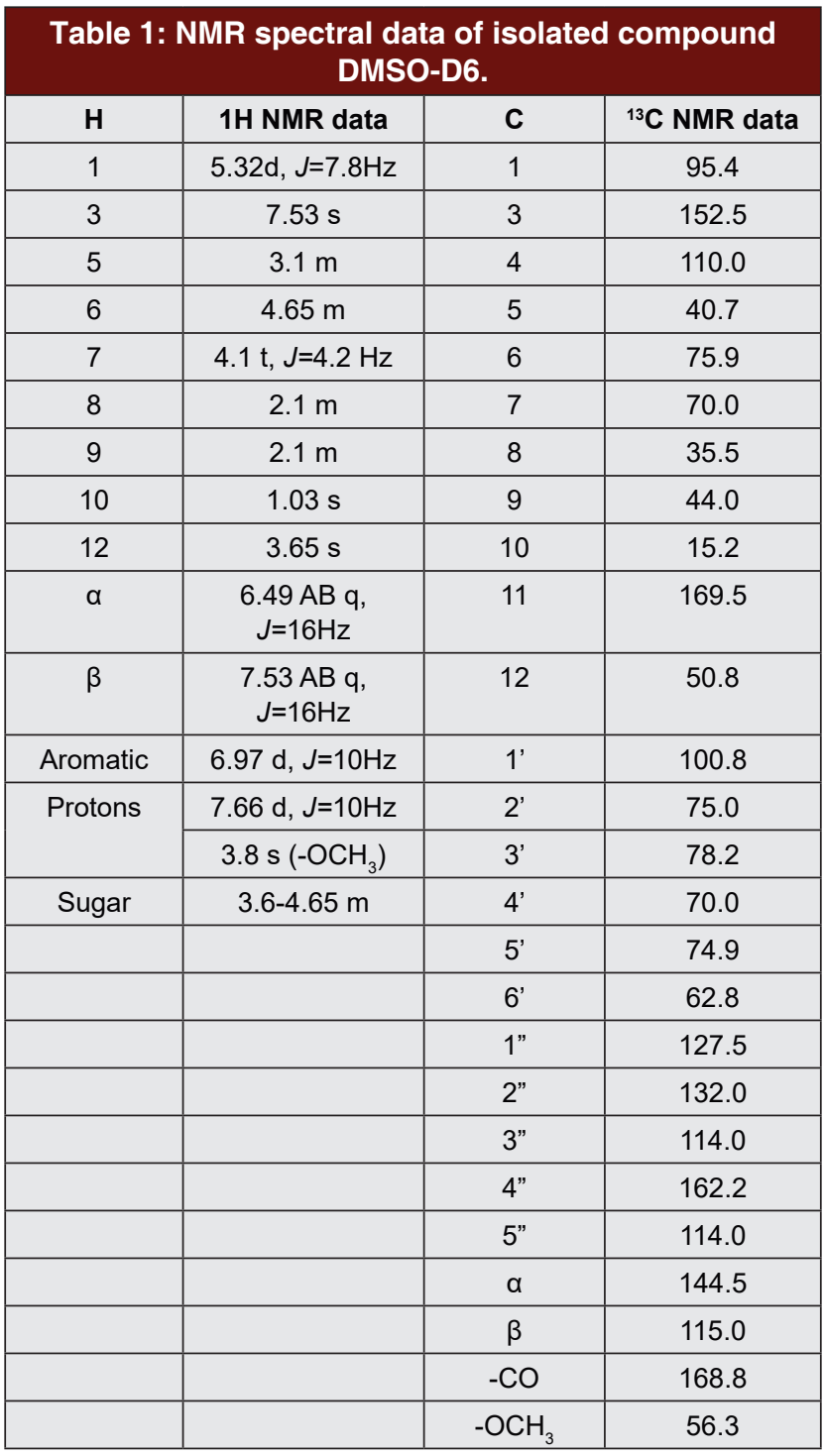
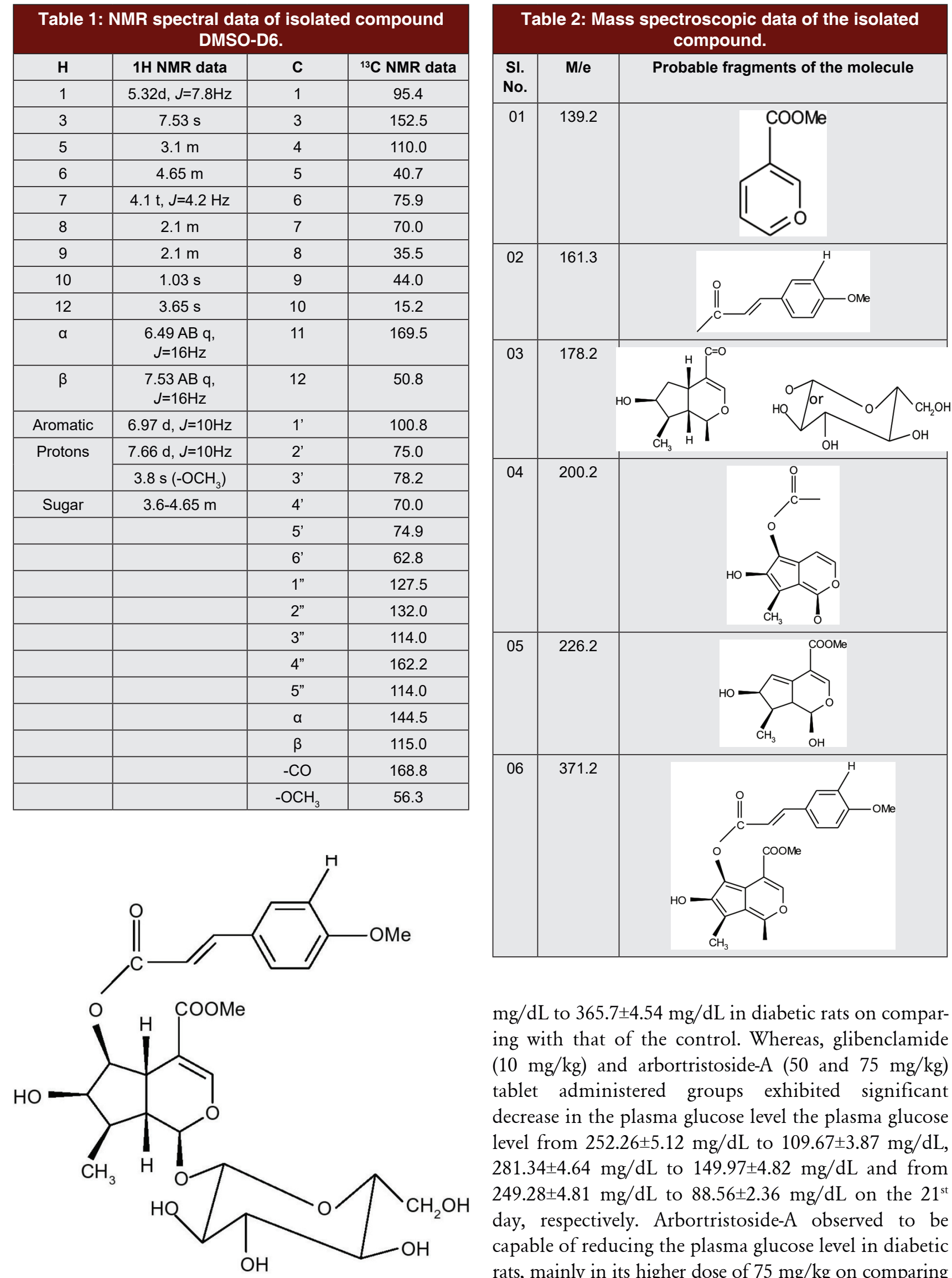

$\mathrm{mg} / \mathrm{dL}$ to $365.7 \pm 4.54 \mathrm{mg} / \mathrm{dL}$ in diabetic rats on comparing with that of the control. Whereas, glibenclamide $(10 \mathrm{mg} / \mathrm{kg})$ and arbortristoside-A (50 and $75 \mathrm{mg} / \mathrm{kg}$ ) tablet administered groups exhibited significant decrease in the plasma glucose level the plasma glucose level from $252.26 \pm 5.12 \mathrm{mg} / \mathrm{dL}$ to $109.67 \pm 3.87 \mathrm{mg} / \mathrm{dL}$, $281.34 \pm 4.64 \mathrm{mg} / \mathrm{dL}$ to $149.97 \pm 4.82 \mathrm{mg} / \mathrm{dL}$ and from $249.28 \pm 4.81 \mathrm{mg} / \mathrm{dL}$ to $88.56 \pm 2.36 \mathrm{mg} / \mathrm{dL}$ on the $21^{\text {st }}$ day, respectively. Arbortristoside-A observed to be capable of reducing the plasma glucose level in diabetic rats, mainly in its higher dose of $75 \mathrm{mg} / \mathrm{kg}$ on comparing Figure 1: Arbortristoside-A. with that of the diabetic control. There was a marked 
Table 3: DPPH radical scavenging activities of arbortristoside-A.

\begin{tabular}{|c|c|c|c|c|c|}
\hline Treatment & $6.25 \mu \mathrm{g} / \mathrm{ml}$ & $12.5 \mu \mathrm{g} / \mathrm{ml}$ & $25 \mu \mathrm{g} / \mathrm{ml}$ & $50 \mu \mathrm{g} / \mathrm{ml}$ & $100 \mu \mathrm{g} / \mathrm{ml}$ \\
\hline Ascorbic acid & $22.68 \pm 1.78$ & $60.37 \pm 2.34$ & $84.21 \pm 3.21$ & $91.56 \pm 2.67$ & $95.76 \pm 2.57$ \\
\hline Arbortristoside-A & $20.67 \pm 1.57$ & $58.38 \pm 1.96$ & $80.67 \pm 2.81$ & $85.71 \pm 2.15$ & $93.43 \pm 2.45$ \\
\hline
\end{tabular}

Values are represented as Mean \pm SEM of triplicate analysis. The observed antioxidant activities of arbortristoside-A are found to be well comparable to that of ascorbic acid.

\begin{tabular}{|c|c|c|c|c|}
\hline \multirow{2}{*}{ Groups } & \multicolumn{4}{|c|}{ Blood glucose level (mg/dl) } \\
\hline & Initial day & Day 7 & Day 14 & Day 21 \\
\hline Normal control & $107.8 \pm 3.18$ & $109.78 \pm 2.46$ & $104.45 \pm 3.96$ & $102 \pm 2.85$ \\
\hline Diabetic control & $247.8 \pm 8.42^{\mathrm{a}}$ & $288.56 \pm 4.78^{a}$ & $317.65 \pm 3.56^{\mathrm{a}}$ & $365.7 \pm 4.54^{\mathrm{a}}$ \\
\hline Diabetes + Glibenclamide & $252.26 \pm 5.12$ & $201.4 \pm 3.96^{* *}$ & $129 \pm 2.25^{\star *}$ & $109.67 \pm 3.87^{* *}$ \\
\hline Diabetes + Arbortristoside-A (50 mg/kg) & $281.34 \pm 4.64$ & $252.91 \pm 2.96^{* *}$ & 224. $4 \pm 1.42^{* *}$ & $149.97 \pm 4.82^{* *}$ \\
\hline Diabetes + Arbortristoside-A (75 mg/kg) & $249.28 \pm 4.81$ & $185.6 \pm 4.62^{* *}$ & $198.8 \pm 2.86^{* *}$ & $88.56 \pm 2.36^{* *}$ \\
\hline
\end{tabular}

The results are represented as mean $\pm S E M$; each group is comprised of $n=6$ animal; ${ }^{a} p<0.01$ compared to normal control; $* * p<0.01$ compared with the diabetic control. One way ANOVA was followed by Dunnett's t-test.

Table 5: Effects of arbortristoside-A (50 and $75 \mathrm{mg} / \mathrm{kg})$ on the lipd profile $(\mathrm{mg} / \mathrm{dL})$ of the diabetic rats.

\begin{tabular}{|c|c|c|c|}
\hline Groups & Total cholesterol & Triglyceride & HDL cholesterol \\
\hline Normal control & $94.16 \pm 2.62$ & $82.6 \pm 2.72$ & $41.62 \pm 2.76$ \\
\hline Diabetic control & $160.66 \pm 2.58 \mathrm{a}$ & $161.5 \pm 2.62 \mathrm{a}$ & $25.24 \pm 1.98 \mathrm{a}$ \\
\hline Diabetes + Glibenclamide & $98.68 \pm 2.34^{* *}$ & $85.26 \pm 2.01^{* *}$ & $38.36 \pm 2.16^{* *}$ \\
\hline Diabetes + Arbortristoside-A $(50 \mathrm{mg} / \mathrm{kg})$ & $127.266 \pm 1.86^{* *}$ & $99.88 \pm 2.14^{* *}$ & $37.5 \pm 1.88^{*}$ \\
\hline Diabetes + Arbortristoside-A $(75 \mathrm{mg} / \mathrm{kg})$ & $94.8 \pm 2.78^{* *}$ & $90.5 \pm 1.98^{* *}$ & $38.66 \pm 1.96^{* *}$ \\
\hline
\end{tabular}

The results are represented as mean $\pm \mathrm{SEM}$; each group is comprised of $n=6$ animal; ${ }^{\text {a }} p<0.01$ compared to normal control; ${ }^{*} p<0.05$ and $* * p<0.01$ compared with the diabetic control. One way ANOVA was followed by Dunnett's t-test.

reduction in blood glucose level (in 21 days) by arbortristoside-A at $75 \mathrm{mg} / \mathrm{kg}(p<0.01)$ which is well comparable to that of glibenclamide $(10 \mathrm{mg} / \mathrm{kg})$ (Table 4). STZ impaired glucose-stimulated insulin release due to its destructive effect on the beta cells of the pancreas, causing marked features of type I diabetes. ${ }^{26}$ The present study showed that the tablet formulation of arbortristoside-A can protect the destruction of beta cells of the pancreas due to diabetes and can treat the ailment effectively.

\section{Effect on biochemical parameters}

Diabetes leads hyperlipidemia due to decreases in HDL levels and raises in triglycerides and LDL levels. STZ significantly increase $(P<0.01)$ of serum total cholesterol (160.66), triglycerides (161.5), and significantly decreased $(P<0.01)$ in HDL (25.24) on comparing with the normal control group. Arbortristoside-A was observed to reduce total cholesterol and triglyceride levels significantly $(p<0.01)$, on the other hand it showed significant $(p<0.01)$ increase in the serum HDL level at its higher dose of $75 \mathrm{mg} / \mathrm{kg}$ after 21 days of its treatment (Table 5). Arbortristoside-A treated groups of animals showed dose dependent overall protection against the dabetes induced hyperlipidemic which is well comparable to glibenclamide treated animals.

It is well evident that insulin normally activated the enzyme lipoprotein lipase causing the hydrolysis of triglycerides. Reduced plasma insulin due to the destruction of $\beta$-cells causes the disturbed lipid profile in diabetes. As arbortristoside exhibited significantly to control the diabetes induced hyperlipidaemia, it supports the improved insulin level may be by the reduced destruction of $\beta$-cells. ${ }^{30}$ In The rise in the serum lipids during diabetes is especially due to decreased insulin-sensitive lipase inhibition causing the enhanced mobilization of fatty acids from the peripheral fat depots. Whereas STZ causes the enhanced plasma fatty acid level due to the liver generation of phospholipids and 


\begin{tabular}{|c|c|c|}
$\begin{array}{c}\text { Table 6: Effect arbortristoside-A (50 and } 75 \mathrm{mg} / \mathrm{kg}) \\
\text { on liver parameters of diabetic rats. }\end{array}$ \\
\hline Groups & $\begin{array}{c}\text { AST or SGOT } \\
\text { (U/L) }\end{array}$ & $\begin{array}{c}\text { ALT or SGPT } \\
\text { (U/L) }\end{array}$ \\
\hline Normal control & $48.33 \pm 2.33$ & $60.16 \pm 2.76$ \\
\hline Diabetic control & $108.83 \pm 3.10^{\mathrm{a}}$ & $116.16 \pm 2.28^{\mathrm{a}}$ \\
\hline $\begin{array}{c}\text { Diabetes + Glibenclamide } \\
\text { Diabetes + Arbortristoside-A } \\
(50 \mathrm{mg} / \mathrm{kg})\end{array}$ & $72.66 \pm 2.08^{* *}$ & $69.85 \pm 1.82^{* *}$ \\
\hline $\begin{array}{c}\text { Diabetes + Arbortristoside-A } \\
(75 \mathrm{mg} / \mathrm{kg})\end{array}$ & $44.16 \pm 1.60^{* *}$ & $56.16 \pm 2.24^{* *}$ \\
\hline
\end{tabular}

The results are represented as mean $\pm \mathrm{SEM}$; each group is comprised of $n=6$ animal; a $p<0.01$ compared to normal control; $* * p<0.01$ compared with the diabetic control. One way ANOVA was followed by Dunnett's t-test

cholesterol which may be discharged into lipoproteins in the plasma with TG to elevate serum phospholipids..$^{30,31}$ Arbortristoside-A reversed the hyperlipidemia induced by STZ and improved the HDL level. ${ }^{31}$

In the present research the seum AST and ALT in the diabetic rats were observed to be significantly $(p<0.01)$ elevated in comparison to the normal control group, whereas arbortristoside-A (50 and $75 \mathrm{mg} / \mathrm{kg}$ ) as well as glibeclamide was onserved to reduce significantly $(p<0.01)$ these enzymes as compared with the diabetic control (Table 6). As a major metabolic part of body, the liver plays a vital role in the homeostasis of glucose and lipid. ${ }^{32}$ Enhanced catabolic processes during diabetes decreases the liver weight. ${ }^{33}$ Glycogen Glycogen is the well recognised indicator of diabetes mellitus and ALT and AST convert amino acids to keto acids. ${ }^{34}$ In diabetic rats induced by STZ, the hepatic dysfunction and hepatotoxicity were indicated by the enhanced serum AST and ALT performance. ${ }^{35}$ On the other hand arbortristoside-A proved to inhibit the serum AST and ALT level supporting its hepatoprotective effect which is one of the important protective feature to manage diabetes.

\section{Effect of arbortristoside-A on histopathology of pancreas and liver}

The pancreas of the normal control rats exhibited round and elongated islets which were distributed uniformly thoughout the pancreas. But in diabetic rats irregular, reduced in number, necrotized, with nuclear karyolysis in some regions beta cells were observed and the size and number of islets were reduced mainly surrounding the central vessel. In treated groups the pancreas showed significant improvement with slight regeneration of beta cells at arbortristoside-A higher

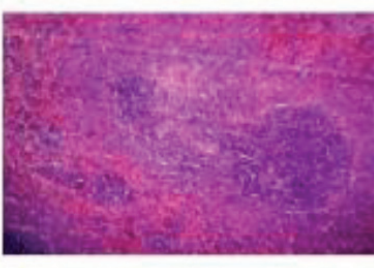

A.

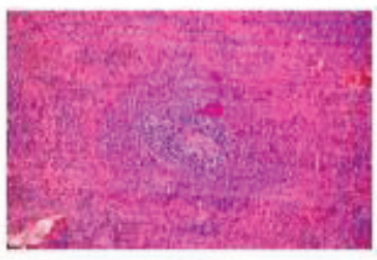

$c$
B.

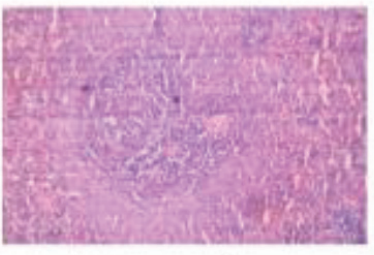

D.
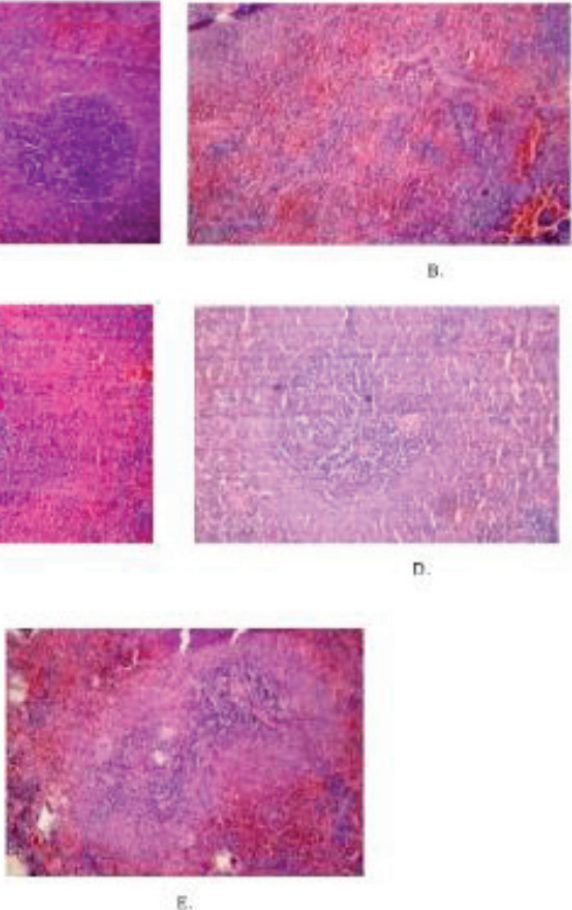

Figure 2: Histopathological changes in rat pancreas. A) Normal control histological structure of rat pancreas showing normal islet B) Diabetic control rat showing irregular cells, not well defined necrosis of cells is very clear C) Glibenclamide (10 $\mathrm{mg} / \mathrm{kg}$ ) treated rat pancreas showing mild protection $D$ ) Arbortristoside-A $(50 \mathrm{mg} / \mathrm{kg})$ treated showed no significant changes in cells were seen when compared with diabetic control E) Arbortristoside-A (75 mg/kg) treated showed regeneration of $\beta$ cells were seen when compared with diabetic control.

dose suggesting restorative effect of arbortristoside- $A$ on pancreatic islet cells (Figure 2).

The normal liver histopathological features were observed in the liver sections of the normal control animals. Whereas, the histopathological examination of the liver of the diabetic rats revealed feathery degeneration, micro and macro cellular fatty changed along with the inflammatory cells surrounding the portal tract. In case of arbortristoside-A (50 and $75 \mathrm{mg} / \mathrm{kg}$ ) and glibenclamide treated animals, there was lesser micro fatty changed in comparison to that of the diabetic control group. These findings suggest that arbortristoside-A can be used to relieve STZ induced toxicity (Figure 3). The histopathological study of the vital organs associated with the occurrence of diabetes also supports the protective property of arbortristoside-A on the organs in the management of diabetes. Potential regenerative effect was observed in arbortristoside- $A$ treated animals. It might be the possible mechanism 


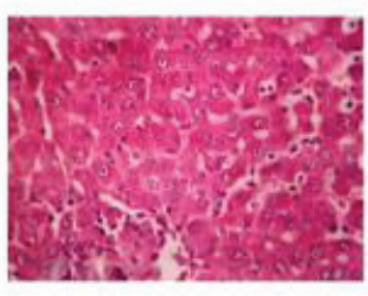

A.

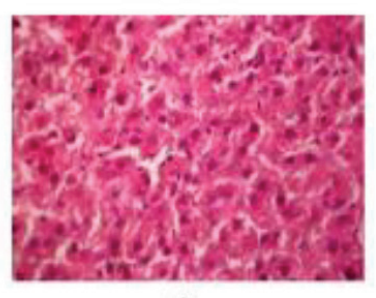

c.

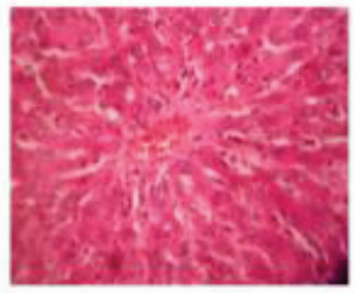

B.

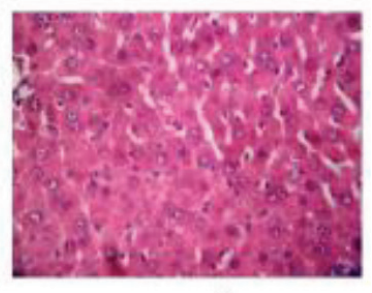

D.

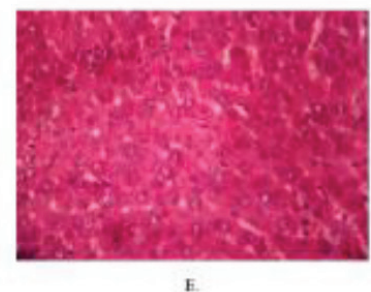

Figure 3: Histopathological changes in the liver of experimental rats. A) Normal control animals showed normal liver architecture B) Diabetic control rat showing feathery degeneration, micro and macro cellular fatty changes and inflammatory cells around portal tract $\mathrm{C})$ Glibenclamide $(10 \mathrm{mg} / \mathrm{kg})$ treated rat liver showing a mild protection D) Arbortristoside-A (50 mg/kg) treated showing less micro and macro cellular fatty changes in comparison to diabetic control group E)

Arbortristoside-A (75 $\mathrm{mg} / \mathrm{kg})$ treated showing no fatty degeneration and showed good protection.

of arbortristoside-A behind improving insulin secretion from the beta cells of the pancreatic islets of the diabetic rats to improve the glucose transport to the peripheral tissue and supporting its antidiabetic activity.

\section{CONCLUSION}

Although the antidiabetic activity of $N$. arbortristis stem extract was previously reported, it is the foremost and novel attempt to study the antidiabetic activity of the tablet formulation of arbortristoside-A from the seeds N. arbortristis. The tablet formulation of arbortristosideA exhibited potent in-vitro and in-vivo pharmacokinetic profiles. Indeed it has been found a dose-dependent antidiabetic effect for arbortristoside-A in STZ induced diabetic rats, where STZ is well evident to cause destruction of the beta cells of islet cells of pancreas inducing diabetes. The histopathological study of the vital organs associated with the occurrence of diabetes also supports the protective property of arbortristoside-A on the organs in the management of diabetes. As the present study has also proved its antioxidant activity which may increase the enzymatic action along with the improved hepatic and pancreatic histological features, it can also be concluded that the antidiabetic activity of arbortristoside-A is also accompanied by its antioxidant property. Besides, arbortristoside-A improves the associated complications of Diabetes Mellitus is characterized by several parameters tested, such as arbortristoside-A showed to decrease lipid profiles like cholesterol and TG level and increase HDL level along with the improvement of histology of pancreas and liver. Whole over study is confirmed the full potential of the tablet formulation of arbortristoside-A obtained from the methanol extract of the leaves of $N$. arbortristis for the therapeutic management of Diabetes Mellitus.

\section{ACKNOWLEDGEMENT}

The authors extend their gratitude to the Director and management of Noida Institute of Engineering and Technology (Pharmacy Institute) for continuous support and providing all kinds of facilities to complete this research.

\section{CONFLICT OF INTEREST}

The authors declare no conflict of interest.

\section{ABBREVIATIONS}

ALT: Alanine Transferase; ANOVA: Analysis of variance; AST: Aspartate Transaminase; AUC 0-5: Area under the curve from $0 \mathrm{hr}-5 \mathrm{hr} ; \mathbf{C}_{\text {max }}$ : Maximum Plasma Concentration; DMSO: Dimethylsulfoxide; DPPH: 2,2-diphenyl-1- picrylhydrazyl; DPX: diphenyl xylene; HDL: High density lipoprotein; HPLC: High Performance Liquid Chromatography; IR: Infra-Red; $\mathrm{KBr}$ (Potassium bromide); LDL: Low Density Lipoprotein; $\mathrm{MeOH}$ (Methanol); N. arbortristis (Nyctanthes arbortristis); NMR: Nuclear Magnetic Resonance; Ms: Mass spectroscopy; STZ: Streptozotocin; TG: Triglycerides; $\mathrm{T}_{\text {max }}$ (Time required to reach the maximum concentration); UV: Ultraviolet; w/v: (Weight/volume).

\section{REFERENCES}

1. Shandilya K, Bhardwaj P, Saxena V, Arora N. Nycatanthes arbour-tritis with special reference to their anti-arthritic activity - a review. Int J Res Appl Sci Eng Technol. 2017;5:1271-75.

2. Bhalakiya H, Modi RN. Traditional medicinal uses, phytochemical profile and pharmacological activities of Nyctanthes arbortristis. Res J Life Sci Bioinformatics. 2019;5:1004-35. 
3. Agrawal J, Pal A. Nyctanthes arbor-tristis Linn-A critical ethnopharmacological review. J Ethnopharmacol. 2013;146(3):645-58. doi: 10.1016/j.jep.2013.01.024.

4. Kirtikar KR, Basu BD. Indian medicinal plants. Vol. 7. Delhi: Sri Satguru Publications; 2000. p. 2110.

5. Rathore A, Juneja RK, Tandon JS. An iridoid glucoside from Nyctanthes arbortristis. PhytoChemistry. 1989;28(7):1913-7. doi: 10.1016/S00319422(00)97886-5.

6. Tuntiwahwuttikul P, Rayanil K, Taylon WC. Chemical constituents from the flowers of Nyctanthes arbortristis. Sci Asia. 2003;29:21-30.

7. Tandon JS, Srivastava V, Guru PY. Iridoids: A new class of leishmanicidal agents from Nyctanthes arbortristis. J Nat Prod. 1991;54(4):1102-4. doi: 10.1021/np50076a030, PMID 1791475.

8. Gupta PP, Srimal RC, Srivastava M, Singh KL, Tandon JS. Antiallergic Activity of Arbortristosides from Nyctanthus Arbortristis. International Journal of Pharmacognosy. 1995;33(1):70-2. doi: 10.3109/13880209509088151.

9. Gupta RS, Kachhawa JBS, Sharma R. Antispermatogenic effect of Nyctanthes arbortristis in male albino rats. Pharmacol Online. 2006;2:261-73.

10. Heendeniya SN, Keerthirathna LR, Manawadu CK, Dissanayake IH, Ali R, Mashhour A, Alzahrani H, Godakumbura P, Boudjelal M, Peiris DC. Therapeutic Efficacy of Nyctanthes arbor-tristis flowers to inhibit proliferation of acute and chronic primary human leukemia cells, with adipocyte differentiation and in silico analysis of interactions between survivin protein and selected secondary metabolites. Biomolecules. 2020;10(2):10(2):165. doi: 10.3390/biom10020165, PMID 31973079.

11. Singh R, Hasan SM, Verma A, Panda SK, Nyctanthes arbor-tristis and its role in the alleviation of arthritic pain: a review. Curr Bioact Compd. 2020;16(8):1-7.

12. Das S, Sasmal D, Basu SP. Anti-inflammatory and antinociceptive activity of Arbortristoside-A. J Ethnopharmacol. 2008;116(1):198-203. doi: 10.1016/j. jep.2007.11.034, PMID 18178352.

13. Patel UM, Patel KM, Patel MP, Bhavasar GC. Anti-inflammatory activity of Nyctanthes arbortristis. Indian J Nat Prod. 1998;14:9-11.

14. Suresh V, Senthilkumar N. Evaluation of antidiabetic activity of Nyctanthes arbortristis in streptozotocin induced diabetic rats, European J Pharm Medic. Resources. 2018;5(03):295-300.

15. Vajravijayan S, Nandhagopal N, Anantha Krishnan D, Gunasekaran K. Isolation and characterization of an iridoid, Arbortristoside-C from Nyctanthes arbortristis Linn., a potential drug candidate for diabetes targeting a-glucosidase. J Biomol Struct Dyn. 2020:1-11. doi: 10.1080/07391102.2020.1813201. PMID 32870131.

16. Suresh V, Jaikumar $\mathrm{S}$, Arunachalam G. Antidiabetic activity of ethanol extract of stem bark of Nyctanthes arbortristis linn. Res J Pharm Biol Chem Sci. 2010;1(4):311-17.

17. Purushothaman KK, Venkatanarasimhan M, Sarada A, Arbortristoside A, B. Two iridoid glucosides from Nyctanthes arbortristis. PhytoChem. 1985;24:773-6.

18. Backette AK, Stenlake JB. Practical pharmaceutical chemistry. CBS publishers and distributors. New Delhi; 1998. p. 63-7.

19. Mendham J, Dennet RC, Bernes JD, Thomas MJK. Text book of quantitative chemical analysis (Vogel's). London: Pearson Education Pvt. Ltd., Indian Branch. New Delhi; 2003. p. 98-102.
20. Das S, Sasmal D, Basu SP. Studies on the bioavailability of Arbortristoside-A from tablet formulations. World J Pharm Pharm Sci. 2014;3(5):1218-28.

21. Belgamwar AV, Gupta AM, Mundhada DR. Fast release carbamazepine tablet for kids. Indian Pharm. 2007;6(63):67-70.

22. Etuk EU. Animals models for studying diabetes mellitus. Agric Biol J N Am. 2010;1(2):130-4.

23. Banu S, Arunachalam G, Jayaveera KN, Ashoka Babu VL, Premakumari KB. Estimation of total phenolic content and in vitro antioxidant activity of Barleria montana. Pharm Lett. 2011;3(4):178-82.

24. Ragavan B, Krishnakumari S. Effect of T. Arjuna stem bark extract on histopathology of liver, kidney and pancreas of alloxan-induced diabetic rats. Afr J Biomed Res. 2006;9(3):189-97. doi: 10.4314/ajbr.v9i3.48904.

25. Eidi A, Eidi M. Antidiabetic effects of sage (Salvia officinalis L.) leaves in normal and streptozotocin-induced diabetic rats. Diab Metab Syndr Clin Res Rev. 2009;3(1):40-4. doi: 10.1016/j.dsx.2008.10.007.

26. Singh AK, Singh J. Evaluation of anti-diabetic potential of leaves and stem of Flacourtia jangomas in streptozotocin-induced diabetic rats. Indian J Pharmacol. 2010;42(5):301-5. doi: 10.4103/0253-7613.70238, PMID 21206623.

27. Kumar R, Gupta A, Singh AK, Bishayee A, Pandey AK. The antioxidant and antihyperglycemic activities of bottlebrush plant (Callistemon lanceolatus) Stem Extracts Medicines. Medicines. 2020;7(11):1-16.

28. Maritim AC, Sanders RA, Watkins JB. Diabetes, oxidative stress, and antioxidants: a review. J Biochem Mol Toxicol. 2003;17(1):24-38. doi: 10.1002/jbt.10058, PMID 12616644

29. Mediani A, Abas F, Khatib A, Tan CP. Cosmos caudatus as a potential source of polyphenolic compounds: optimisation of oven drying conditions and characterisation of its functional properties. Molecules. 2013;18(9):10452-64. doi: 10.3390/molecules180910452, PMID 23994970.

30. Rajagopal K, Sasikala K. Antihyperglycaemic and antihyperlipidaemic effects of Nymphaea stellata in alloxan-induced diabetic rats. Singapore Med J. 2008;49(2):137-41. PMID 18301841.

31. Maiti A, Dewanjee S, Jana G, Mandal SC. Hypoglycemic effect of $<i>$ Swietenia macrophylla</i> seeds against type II diabetes. Int J Green Pharm. 2008;2(4):224-7. doi: 10.4103/0973-8258.44738.

32. Saravanan G, Pari L. Effect of Cogent db, a herbal drug, on serum and tissue lipid metabolism in experimental hyperglycaemic rats. Diabetes Obes Metab. 2003;5(3):156-62. doi: 10.1046/j.1463-1326.2003.00257.x, PMID 12681022.

33. Yadav UC, Moorthy K, Baquer NZ. Combined treatment of sodium orthovanadate and Momordica charantia fruit extract prevents alterations in lipid profile and lipogenic enzymes in alloxan diabetic rats. Mol Cell Biochem. 2005;268(1-2):111-20. doi: 10.1007/s11010-005-3703-y. PMID 15724444.

34. Whitehead MW, Hawkes ND, Hainsworth I, Kingham JGC. A prospective study of the causes of notably raised aspartate aminotransferase of liver origin. Gut. 1999;45(1):129-33. doi: 10.1136/gut.45.1.129, PMID 10369716.

35. Larcan A, Lambert H, Laprevote-Heully MC, Delorme N. Light and electron microscopic study of hepatic lesions in the course of hyperlactatemia in diabetic patients (author's transI). Diabete Metab. 1979;5(2):103-12. PMID 113262. 


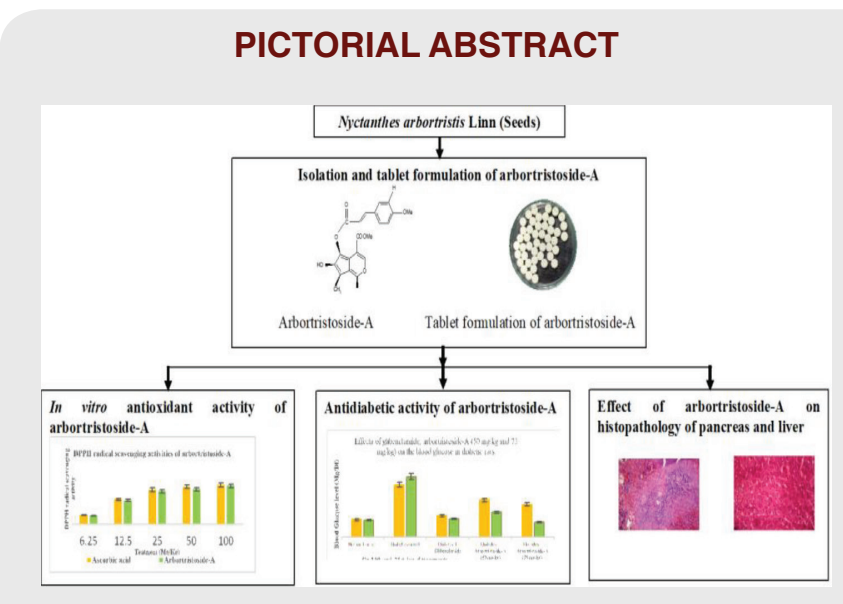

About Authors

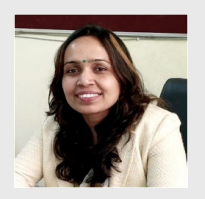

Dr Sanjita Das: Professor and HOD, Pharmacology,Noida Institute of Engineering and Technology (Pharmacy Institute), Greater Noida.

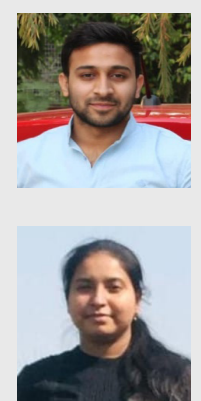

Irfan Khan, M Pharm (Pharmacology), Noida Institute of Engineering and Technology (Pharmacy Institute), Greater Noida.

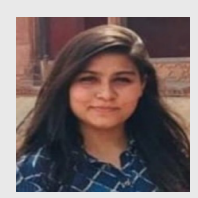

Shivani Shivastava, M Pharm (Pharmacology), Noida Institute of Engineering and Technology (Pharmacy Institute), Greater Noida.

Ms Shruti Dhasmana: M Pharm (Pharmacology), Noida Institute of Engineering and Technology (Pharmacy Institute), Greater Noida.

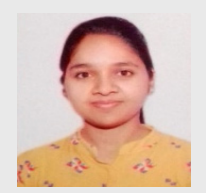

KM Renu Singh, M Pharm (Pharmacology), Noida Institute of Engineering and Technology (Pharmacy Institute), Greater Noida.

\section{SUMMARY}

- Nyctanthes arbortristis Linn. is scientifically proved to possess several potentialities for the ailments of different disorders along with its traditional use in this field. From literature the antidiabetic potentiality of its leaves and the extensive search of a potent agent for the overall management of diabetes targeted the research to formulate the tablets of arbortristoside-A from the seeds of $N$. arbortristis seeds and further screen its anti- diabetic, hypolipidemic and antioxidant properties.

- Arbortristoside-A was chemically isolated and spectro- photometrically identified from the ethanolic extract of $N$. arbortristis. It was again supported by the in-vitro evaluation of the antioxidant activity of arbortristo- side-A following DPPH (2,2-diphenyl-1-picrylhydrazyl) method. Its tablets were formulated by wet granulation method using rotating punch tablet machine. After standard evaluation of the tablets their antidiabetic activity was estimated using streptozotocin-induced diabetic wistar albino rats. The study was confirmed by systematic evaluation of the serum biochemical assays along with the pancreatic and hepatic histopathology. Arbortristoside-A tablets were observed to reduce the blood glucose, serum cholesterol $(p<0.01)$, triglycerides, AST and ALT levels significantly. On the other hand, the HDLcholesterol level was found to be enhanced by its treatment which was well comparable to that of the standard drug glibenclamide. Histopathological inves- tigation confirmed significant recovery of both the pancreatic and hepatic damage due to diabetes which was supported by observed antioxidant potentiality of arbortristoside-A.

Cite this article: Das S, Khan I, Dhasmana S, Shrivastava S, Singh R. Formulation and Evaluation of the Antidiabetic, Hypolipidemic and Antioxidant Potential of the Tablets of Arbortristoside-A from the Seeds of Nyctanthes arbortristis Linn. Indian J of Pharmaceutical Education and Research. 2021;55(4):1074-83. 